\title{
RESEARCH ON ATHLETE'S AEROBIC AND ANAEROBIC EXERCISE ABILITY WITH BALANCED NUTRITION
}

\author{
PESQUISA SOBREA CAPACIDADE DE EXERCÍCIO AERÓBIO E ANAERÓBIO DO ATLETA COM NUTRIÇÃO \\ BALANCEADA
}

INVESTIGACIÓN SOBRE LA CAPACIDAD DE EJERCICIO AERÓBICO Y ANAERÓBICO DE LOS ATLETAS
CON UNA NUTRICIÓN EQUILIBRADA

Yunfei Yang' (1D

(Physical Education Professional)

Jingwei Yang ${ }^{1,2} \mathbb{D}$

(Physical Education Professional)

1. School of Physical Education, Central China Normal University, Wuhan, China.

2. School of Physical Education, Xinyang Normal University,

Xinyang, China.

\section{Correspondence:}

Jingwei Yang, School of Physical Education, Central China Normal University, Wuhan, 430000, China. yjw1227@126.com

\begin{abstract}
Introduction: The need for a lactic acid cycle eliminates lactic acid produced during exercise. This process requires energy consumption. D-ribose supplementation can increase muscle cell energy, accelerate the synthesis of PRPP in the heart and skeletal muscle, and eliminate the pentose phosphate pathway in the low limit of glucose6-phosphate dehydrogenase activity; it doubles the speed of ATP recovery, so supplementing ribose can improve exercise capacity and accelerate the elimination of lactic acid to improve recovery ability. Objective: Supplementing D-ribose can increase muscle cell energy and accelerate the regeneration of ATP in the myocardium and skeletal muscle. This experiment intends to explore the effects of anaerobic and aerobic exercise and anaerobic exercise capacity and recovery ability after supplementing D-ribose granules by observing the changes in exercise tests before and after nutritional supplementation and recovery indicators after exercise. Methods: The thesis used a paired design to randomly divide 24 male amateur tennis players into two groups (12 in each group): physical training group (control group), physical training + nutrition D-ribose group (test group), and the D- The effect of ribose on the aerobic and anaerobic exercise capacity of amateur tennis players. Results: The observation indexes of the two groups before the test were not statistically significant ( $P>0.05)$; after the test for eight weeks, the aerobic capacity indexes of the test group were higher than those of the control group $(P<0.05)$, and also higher than those before the test $(P<0.05))$; The recovery of $3 \mathrm{minHR}$ and $5 \mathrm{minHR}$ of the experimental group after exercise was significantly faster than that of the control group $(P<0.05)$. Conclusions: Nutritional D-ribose supplementation can enhance the aerobic training effect of amateur tennis players, improve aerobic and anaerobic exercise capacity, and accelerate heart rate recovery after exercise. Level of evidence II; Therapeutic studies - investigation of treatment results.
\end{abstract}

Keywords: Exercise; Heart rate; Nutrition assessment; Ribose; Lactic acid.

\section{RESUMO}

Introdução: A necessidade de um ciclo de ácido lático elimina o ácido lático produzido durante o exercício. Este processo requer consumo de energia. A suplementação com D-ribose pode aumentar a energia das células musculares, acelerar a síntese de PRPP no coração e no músculo esquelético e eliminar a via da pentose fosfato no limite inferior da atividade da glicose-6-fosfato desidrogenase; ele dobra a velocidade de recuperação de ATP, portanto, a suplementação de ribose pode melhorar a capacidade de exercício e acelerar a eliminação de ácido láctico para melhorar a capacidade de recuperação. Objetivo: A suplementação de D-ribose pode aumentar a energia das células musculares e acelerar a regeneração de ATP no miocárdio e músculo esquelético. Este experimento pretende explorar os efeitos do exercício anaeróbio e aeróbio e da capacidade de exercício anaeróbio e capacidade de recuperação após a suplementação de grânulos de D-ribose, observando as mudanças nos testes de exercício antes e após a suplementação nutricional e indicadores de recuperação após o exercício. Métodos: A tese utilizou um desenho pareado para dividir aleatoriamente 24 tenistas amadores do sexo masculino em dois grupos (12 em cada grupo): grupo de treinamento físico (grupo controle), grupo de treinamento físico + nutrição D-ribose (grupo de teste) e o grupo D - O efeito da ribose na capacidade de exercício aeróbio e anaeróbio de tenistas amadores. Resultados: Os indices de observação dos dois grupos antes do teste não foram estatisticamente significantes $(P>0,05)$; após o teste por oito semanas, os índices de capacidade aeróbia do grupo teste foram maiores do que os do grupo controle ( $P$ $<0,05)$, e também maiores do que aqueles antes do teste $(P<0,05)$; A recuperação de 3 minHR e 5 minHR do grupo experimental após o exercício foi significativamente mais rápida do que a do grupo controle $(P<0,05)$. Conclusões: A suplementação nutricional de D-ribose pode aumentar o efeito do treinamento aeróbio de jogadores de tênis amadores, melhorar a capacidade de exercício aeróbio e anaeróbio e acelerar a recuperação da freqüência cardíaca após o exercício. Nível de evidência ll; Estudos terapêuticos - investigação dos resultados do tratamento.

Descritores: Exercício físico; Frequência cardiaca; Avaliação nutricional; Ribose; Ácido láctico.

\section{RESUMEN}

Introducción: La actividad física regular ayuda a mejorar las habilidades cardiovasculares y cerebrovasculares. Cómo evaluar la tensión nerviosa de los vasos cardiovasculares y cerebrovasculares a través del deporte es un 
tema candente. Objetivo: El artículo analiza la influencia de la participación regular en deportes sobre la función cardiovascular de las personas y los indicadores relacionados con la sangre. Métodos: Seleccionamos a 30 adultos mayores sanos que participan regularmente en deportes, registramos sus cambios en el ECG, presión arterial, frecuencia cardíaca y otros indicadores relacionados con la función cardiovascular, y analizamos la función sanguínea de los ancianos. Detección del recuento de glóbulos rojos (RBC), volumen de glóbulos rojos (MCV) y hemoglobina (Hb), creatinina sérica (Cr), glucosa en sangre (BGS), triglicéridos (TG), colesterol (TC), lipoproteínas de baja densidad (LDL) y se mide la lipoproteína de alta densidad (HDL). Resultados: Los adultos mayores que persisten en el ejercicio durante mucho tiempo tienen mejores indicadores que los que no lo hacen. Conclusión: El ejercicio aeróbico adecuado puede reducir la rigidez de los vasos sanguíneos en los ancianos. El ejercicio puede ayudar a los ancianos a aumentar la variabilidad de la frecuencia cardiaca y mejorar los indicadores sanguíneos y la masa corporal de la función nerviosa autónoma del corazón. Nivel de evidencia ll; Estudios terapéuticos: investigación de los resultados del tratamiento.

Descriptores: Ejercicio físico; Frecuencia cardíaca; Evluación nutriconal; Ribose; Ácido láctico.

\section{INTRODUCTION}

Tennis is a skill-led competition against the net, but in the course of sports, especially in a game that takes three or four hours, tennis players need to consume a lot of physical energy. Therefore, some researchers believe that the aerobic and anaerobic exercise capacity of tennis players is a prerequisite for the completion of a large-volume competition. Among the many powerful methods, nutritional supplements are the most common, and nutrient supplements or nutritional supplements with specific effects can be applied as needed.

\section{METHOD}

\section{Research object}

The thesis uses a paired design to randomly divide 24 male amateur tennis players into 2 groups: physical training group (control group), physical training + D-ribose group (experimental group), 12 in each group. The physical training group (control group) was $21.2 \pm 0.8$ years old, the height was $172.6 \pm 4.8 \mathrm{~cm}$, and the weight was $64.7 \pm 4.9 \mathrm{~kg}$; the physical training + nutrition D-ribose group (test group) was $21.5 \pm 0.6$ years old, and the height was $173.0 \pm 4.1 \mathrm{~cm}$. Body weight is $64.9 \pm 4.7 \mathrm{~kg}$. There was no significant difference in age, height and weight between the two groups ( $P>0.05)$. Table 1 shows the basic information of the research object.

\section{Physical training plan and evaluation}

The physical training programs for the two groups of observation objects are: $1500 \mathrm{~m} \times 1$ group, $800 \mathrm{~m} \times 2$ group, push-up $20 \times 4$ groups, tortuous path exercise $5 \mathrm{~min} \times 2$ group on Tuesday; $1500 \mathrm{~m} \times 1$ group, $800 \mathrm{~m} \times 2$ group, Horizontal bar pull-ups $20 \times 3$ groups, 4 -point cyclical movement exercises 5 min $\times 2$ groups; Saturdays $1500 \mathrm{~m} \times 1$ group, $800 \mathrm{~m} \times 2$ groups, weight curls $20 \times 4$ groups, step change jump $3 \mathrm{~min} \times 4$ groups. At the same time, the same tennis skill training plan was completed every day for 8 consecutive weeks. Perform various index tests before and after training.

\section{Sports nutrition supplement program}

The experimental group was supplemented with Dr. Li's D-ribose granules, and the control group was supplemented with a placebo

Table 1. Basic information of research objects.

\begin{tabular}{c|c|c|c|c|c}
\hline Group & $\mathbf{n}$ & Age(y) & Height $(\mathbf{c m})$ & Weight $(\mathbf{k g})$ & Sports years (y) \\
\hline Test group & 12 & $22 \pm 2$ & $181.29 \pm 5.22$ & $71.43 \pm 11.55$ & $5.1 \pm 2.4$ \\
\hline Control group & 12 & $22 \pm 2$ & $182.50 \pm 7.87$ & $77.50 \pm 13.98$ & $5.3 \pm 1.7$ \\
\hline
\end{tabular}

(Sorbitol and $\beta$-cyclodextrin are common polysaccharides, mostly used as sweeteners, taste and taste are the same as D-ribose granules), once a day, $12 \mathrm{~g}$ each time, 7 days a week, for four consecutive weeks.

\section{Determination of aerobic capacity}

Both the control group and the test group used Japan's COMBIWELLNESS company to develop aerobic power bicycles (AEROBIKE75XL II) before the test, and the maximum oxygen uptake $\left(\mathrm{VO}_{2 \max }(\mathrm{ml} /(\mathrm{kg} \cdot \mathrm{min}))\right.$; the oxygen uptake at $75 \%$ of the maximum heart rate $\left(\mathrm{VO}_{2} 75 \% \mathrm{HR}_{\max }\right.$ $(\mathrm{L} / \mathrm{min}))$; Oxygen uptake weight ratio at $75 \%$ maximum heart rate $\left(\mathrm{VO}_{2}\right.$ $75 \% \mathrm{HR}_{\max } /$ Weight ( $\left.\mathrm{ml} /(\mathrm{kg} \cdot \mathrm{min})\right) ;$ power at $75 \%$ maximum heart rate (PWC 75\% HR $\max (\mathrm{W})$ ). The sitting posture adjustment of the aerobic power bicycle $\rightarrow$ input the gender, age and weight of the test subjec$t \rightarrow$ install the ear clip photoelectric pulse sensor $\rightarrow$ the subject enters a quiet state $\rightarrow$ start exercise, the exercise load starts from $5 \mathrm{~W}$, exercise After 90 s, the load is increased by $10 \mathrm{~W} / \mathrm{min}$ until $75 \%$ of the maximum heart rate appears, and the load does not increase until the end of the test. ${ }^{1}$ The pedaling speed is $50 \mathrm{r} / \mathrm{min}$, and the maximum heart rate at rest, immediately after exercise, 3, $5 \mathrm{~min}$ after exercise is recorded at the same time (HR); Repeat the above test after 8 weeks.

\section{VECTOR SPACE MODELING OF HUMAN MOTION CAPTURE DATA}

\section{Vector space representation and motion retrieval}

In order to retain the timing information of the motion, this article uses Bigram VSM to represent the motion document in the form of a vector: whenever a "word switch" appears, the frequency of the binary word corresponding to this "word switch" in the motion vector is increased by 1 , so that the iThe motion segments $S_{i}^{(u)}$ cand $S_{i}^{(1)}$ are represented as motion vectors $\Theta_{i}^{(u)}=\left\{\theta_{i, 1}^{(u)}, \theta_{i{ }^{2}}^{(u)}, \cdots, \theta_{i, H_{u}}^{(u)}\right\}$ and $\Theta_{i}^{(1)}=\left\{\theta_{i, 1}^{(u)}, \theta_{i, 2}^{(u)}, \cdots, \theta_{i, H_{1}}^{(u)}\right\}$ , respectively, where $\theta_{i, j}^{(u)}$ represents the frequency of $b_{j}^{(u)}$ in the i motion document, $\theta_{i, k}^{(1)}$ represents the frequency of $b_{k}^{(u)}$ in the i motion document, $i=1,2, \cdots, M ; j=1,2, \cdots, H_{u} ; k=1,2, \cdots, H_{1}$. As shown in Figure 1. In the upper body motion document with the arms moving forward, the word $5 \rightarrow 1,1 \rightarrow 2,2 \rightarrow 4,4 \rightarrow 12,12 \rightarrow 3,3 \rightarrow 13$ is switched. ${ }^{2}$ According to the positions of the above-mentioned "phrases" in the binary vocabulary, the corresponding component values of the motion vectors are all increased by 1 .

\section{Weight adjustment of binary motion words}

After the document is adjusted by word frequency, the importance of the word is determined by the number of occurrences and the 
amplitude of the action. ${ }^{3}$ The amplitude of the motion is mathematically expressed as weight, calculation method and the steps to adjust word frequency are as follows:

Step1. It is up to the person to choose a standard standing posture (legs stand upright, shoulder-width apart, arms naturally droop on the side of the body, neck and lumbar spine upright), record it as $f_{s p}$, and break it into two parts of the upper and lower body, $f_{s p}^{(u)}$ and $f_{s p}^{(1)}$.

Step2. The paper finds the distance between each word $b_{\dot{j}}^{(u)}=\left(v_{*}^{(u)}, v^{(u)}\right)$ and $f_{s p}^{(u)}$ in the vocabulary list $B^{(u)}$, and obtains $d_{j}^{(u)} *$ and $d_{j+}^{(u)}$, where $j=1,2, \cdots, H_{\mu}$; finds the distance between each word $b_{k}^{(1)}=\left(v_{*}^{(1)}, v_{+}^{(1)}\right)$ and $f_{s p}^{(1)^{u}}$ in the vocabulary list $B^{(1)}$ , and obtains $d_{k}^{(1)}$, ${ }^{*}$ and $d_{k,+}^{(1)}$, where $k=1,2, \cdots, H_{1}, v *$ and $v+$ are respectively It is the two words before and after the two-tuple. The measurement method also used

Step3. Let $d_{j}^{(\mathrm{u})}=d_{j, *}^{(\mathrm{u})}+d_{j,+}^{(\mathrm{u})}, d_{k}^{(\mathrm{l})}=d_{k, *}^{(\mathrm{u})}+d_{k,+}^{(\mathrm{u})}$ and the obtained $d_{j}^{(\mathrm{u})}$ and $d_{k}^{(1)}$ are respectively normalized to the range of $[0,1]$. The normalized distance is recorded as $\hat{d}_{j}^{(\mathrm{u})}$ and $\hat{d}_{k}^{(\mathrm{l})}$. The vocabulary can be obtained by formula (1) The magnitude weight of each word.

$$
\begin{aligned}
& \varpi_{j}^{(u)}=e^{2} \hat{d}_{j}^{(u)}, j=1,2, \cdots, H_{u}, \\
& \varpi_{k}^{(\mathrm{l})}=e^{2} \hat{d}_{k}^{(1)}, k=1,2, \cdots, H_{1},
\end{aligned}
$$

Step4. The frequency $\theta_{i, j}^{(u)}$ and $\theta_{i, k}^{(u)}$ of the words $b_{j}^{(u)}$ and $b_{k}^{(1)}$ in the final motion vector are adjusted to $\hat{\theta}_{i, j}^{(u)}=\theta_{i, j}^{(u)} \circ \omega_{j}^{(u)}$ and $\hat{\theta}_{i, k}^{(\mathrm{l})}=\theta_{i, k}^{(\mathrm{l})} \circ \omega_{k}^{(\mathrm{l})}$. This value is proportional to the importance of the words in the text document. ${ }^{4}$

Step5. Normalize the motion vectors $\widehat{\Theta}_{i}^{(\mathrm{u})}=\left\{\hat{\theta}_{i, 1}^{(\mathrm{u})}, \hat{\theta}_{i, 2}^{(\mathrm{u})}, \cdots, \hat{\theta}_{i, H_{\mathrm{u}}}^{(\mathrm{u})}\right\}$ and $\widehat{\Theta}_{i}^{(1)}=\left\{\hat{\theta}_{i, 1}^{(1)}, \hat{\theta}_{i, 2}^{(1)}, \cdots, \hat{\theta}_{i, H_{1}}^{(1)}\right\}$ of the upper and lower body and merge them to obtain $\widehat{\Theta}_{i}$.

\section{Statistical processing}

All results are expressed as the mean \pm standard deviation, and the analysis of differences between groups adopts paired sample t test, and the significance level is 0.05 . The statistical data is completed in the statistical software (SPSS17.0 version).

\section{TEST RESULTS}

\section{Determination of aerobic capacity of subjects before and after the test}

Before oral nutritional D-ribose supplements, $\mathrm{VO}_{2 \text { max }}, \mathrm{VO}_{2} 75 \% \mathrm{HR}_{\max }$ $\mathrm{VO}_{2} 75 \% \mathrm{HR}_{\max }$ /weight, PWC 75\% $\mathrm{HR}_{\max }$ were not significantly different between the experimental group and the control group ( $P>0.05)$, suggesting that the experimental design is balanced. The test was repeated after 8 weeks of oral nutritional D-ribose supplement, and the indexes of the test group were significantly higher than those of the control group ( $<<0.05$ ) (Table 2 and 3 ).

\section{ANAEROBIC POWER TEST RESULTS}

\section{Anaerobic power test index}

The results of the anaerobic power test are shown in Table 4 below. The results showed that the two maximum power peaks in the anaerobic power test results of the experimental group were significantly different from each other four weeks later than four weeks ago. ${ }^{5}$

\section{Anaerobic power recovery test indicators}

The blood lactic acid index results of the anaerobic recovery test are shown in Table 6 below. According to the self-comparison of the lactic acid recovery test of the experimental group, the blood lactic acid value at 5 minutes after exercise was lower than that of four
Table 2. Comparison of $\mathrm{VO}_{2 \max }$ and $\mathrm{VO}_{2} 75 \% \mathrm{HR}_{\max }$ results of subjects before and after the test.

\begin{tabular}{c|c|c|c|c|c}
\hline \multirow{2}{*}{ Grouping } & \multirow{2}{*}{$\mathbf{n}$} & \multicolumn{2}{|c|}{$\mathbf{V O}_{2 \max } / \mathbf{m l} \cdot(\mathbf{k g} \cdot \mathbf{m i n})^{-1}$} & \multicolumn{2}{|c}{$\mathbf{V O}_{\mathbf{2}} \mathbf{7 5 \%} \mathrm{HR}_{\max } / \mathbf{L} \cdot \mathbf{m i n}^{-1}$} \\
\cline { 3 - 6 } & & $\begin{array}{c}\text { Before the } \\
\text { experiment }\end{array}$ & $\begin{array}{c}\text { After the } \\
\text { experiment }\end{array}$ & $\begin{array}{c}\text { Before the } \\
\text { experiment }\end{array}$ & $\begin{array}{c}\text { After the } \\
\text { experiment }\end{array}$ \\
\hline Control group & 12 & $42.05 \pm 3.79$ & $43.11 \pm 3.52$ & $1.73 \pm 0.19$ & $1.81 \pm 0.21$ \\
\hline Test group & 12 & $41.89 \pm 3.76$ & $48.29 \pm 4.14$ & $1.76 \pm 0.18$ & $2.18 \pm 0.24$ \\
\hline
\end{tabular}

Table 3. Comparison of $\mathrm{VO}_{2} 75 \% \mathrm{HR}_{\max }$ /Weight and PWC $75 \% \mathrm{HR}_{\max }$ before and

\begin{tabular}{|c|c|c|c|c|c|}
\hline \multirow{2}{*}{ Grouping } & \multirow{2}{*}{$\mathrm{n}$} & \multicolumn{2}{|c|}{$\begin{array}{c}\mathrm{VO}_{2} 75 \% \mathrm{HR}_{\max } / \text { Weight} / \\
\mathrm{ml} \cdot(\mathrm{kg} \cdot \min )^{-1}\end{array}$} & \multicolumn{2}{|c|}{$\mathrm{PWC75}^{2} \mathrm{HR}_{\max } / \mathrm{W}$} \\
\hline & & $\begin{array}{l}\text { Before } \\
\text { the test }\end{array}$ & After the test & $\begin{array}{l}\text { Before } \\
\text { the test }\end{array}$ & After the test \\
\hline Control group & 12 & $26.19 \pm 2.68$ & $28.36 \pm 2.35$ & $154.91 \pm 14.12$ & $159.75 \pm 13.03$ \\
\hline Test group & 12 & $27.47 \pm 2.20$ & $31.88 \pm 2.27$ & $153.08 \pm 13.90$ & $189.41 \pm 16.00$ \\
\hline
\end{tabular}
after the test.

Table 4. Anaerobic power test results.

\begin{tabular}{c|c|c|c|c|c|c}
\hline \multirow{2}{*}{} & \multicolumn{2}{|c|}{$\begin{array}{c}\text { Maximum } \\
\text { power }(\mathbf{w} / \mathbf{k g})\end{array}$} & \multicolumn{2}{c|}{$\begin{array}{c}\text { Average power } \\
\text { (w/kg) }\end{array}$} & \multicolumn{2}{c}{ Fatigue index (\%) } \\
\cline { 2 - 7 } & before & Rear & before & Rear & before & Rear \\
\hline $\begin{array}{c}\text { Test } \\
\text { group }\end{array}$ & $14.90 \pm 1.83$ & $15.71 \pm 2.00$ & $7.93 \pm 0.79$ & $8.35 \pm 1.03$ & $50.28 \pm 10.59$ & $43.44 \pm 12.06$ \\
\hline $\begin{array}{c}\text { Control } \\
\text { group }\end{array}$ & $13.95 \pm 1.40$ & $14.50 \pm 1.07$ & $7.90 \pm 1.08$ & $8.31 \pm 0.70$ & $46.13 \pm 12.38$ & $44.60 \pm 14.60$ \\
\hline
\end{tabular}

weeks before, which has a significant difference; the blood lactic acid value and peak value of blood lactic acid at 9 minutes after exercise were lower than that of four weeks before, which has a very significant difference; Compared with the experimental group and the control group, the lactic acid clearance rate of the experimental group was higher than that of the control group after four weeks, and there was a significant difference.

The heart rate index results of the anaerobic recovery test are shown in Table 8 below. The two heart rate recovery tests in the experimental group were compared by themselves. After four weeks, the heart rate of 2 minutes after exercise and the heart rate of 3 minutes after exercise were lower than that of four weeks ago. There were significant differences; the heart rate recovery values after four weeks were all faster Four weeks ago, there was a significant difference.

\section{DISCUSSION}

The design of this experiment is to observe the effects of oral nutritional D-ribose supplements for amateur tennis players on the improvement of aerobic and anaerobic exercise capacity, in order to explore the effects of nutritional D-ribose supplements on the endurance quality of tennis players. $\mathrm{VO}_{2 \max }$ is a comprehensive index reflecting the body's aerobic work capacity. It mainly depends on the heart's pumping function, and of course it is also related to the muscle's ability to use oxygen. The test observed that after taking D-ribose, $\mathrm{VO}_{2 \max }, \mathrm{VO}_{2} 75 \% \mathrm{HR}_{\max }, \mathrm{VO}_{2} 75 \%$ $H R_{\text {max }}$ Neight, PWC 75\% HR $\mathrm{H}_{\text {max }}$ the above indicators in the test group were significantly higher than those in the control group $(P<0.05)$, and the results suggest oral nutrition D-ribose supplements can improve the aerobic capacity of amateur tennis players. Because the training intensity and training volume of the two groups of test subjects are equal, it is speculated that the effect of nutritional supplements on aerobic training may be achieved by lowering the exercise load threshold.

\section{CONCLUSION}

Supplementing D-ribose can effectively improve the aerobic and anaerobic exercise capacity of amateur tennis players, and at the same 
time can make the athlete's heart rate recover faster after increasing load exercise. Supplementing D-ribose has a certain effect on the 30s anaerobic performance of tennis players; supplementing D-ribose can improve the speed endurance of athletes in high-intensity intermittent exercise. Supplementing D-ribose can increase the ratio of phosphate source energy supplied by male athletes during anaerobic exercise, reduce the ratio of energy supplied by glycolysis, and reduce the production of lactic acid. Supplementing D-ribose can promote the recovery of athletes' heart rate after anaerobic exercise.

All authors declare no potential conflict of interest related to this article

AUTHORS' CONTRIBUTIONS: Each author made significant individual contributions to this manuscript. Jingwei Yang: writing and performing surgeries; Yunfei Yang: data analysis and performing surgeries, article review and intellectual concept of the article.

\section{REFERENCES}

1. Douzi W, Dugué B, Vinches L, AI Sayed C, Hallé S, Bosquet L, et al. Cooling during exercise enhances performances, but the cooled body areas matter: A systematic review with meta-analyses. Scand J Med Sci Sports. 2019;29(11):1660-76.

2. Choi HM, Kim TH. A randomized controlled trial of moderate-intensity circuit band resistance exercise program improve aerobic exercise ability in older adults. Iran J Public Health. 2019;48(5):971-3.
3. Kim IK, Kang SH. Effects of aerobic exercise on blood pressure response during exercise. Iran J Public Health. 2019;48(9):1738-40.

4. Westerterp KR. Exercise, energy balance and body composition. Eur J Clin Nutr. 2018;72(9):1246-50

5. Yu F, Vock DM, Barclay TR. Executive function: Responses to aerobic exercise in Alzheimer's disease. Geriatr Nurs. 2018;39(2):219-24. 